\title{
口腔扁平上皮癌における頸部郭清例の検討
}

\author{
西村泰一・吉田裕一・大坪誠治・竹川政範*
}

末次博・松田光悦・北進一池畑正宏*

\section{Study on cases of oral squamous cell carcinoma with radical neck dissection}

\author{
Taiichi Nishimura • Yuichi Yoshida • Seiji Ohtsubo \\ Masanori Takekawa* ${ }^{*}$ Hiroshi Suetsugu - Mitsuyoshi Matsuda \\ Shin-ichi Kita * Masahiro IKeHATA*
}

\begin{abstract}
Clinicostatistical investigation was made on about 53 patients with squamous cell carcinoma of the oral cavity who had undergone neck dissection at the Department of Oral and Maxillofacial Surgery, Asahikawa Medical College from January 1979 to December 1988.

Of the 71 cases of neck dissection, 50 were performed therapeutically, and 21 prophylactically. Metastases to the cervical lymph nodes were histologically confirmed in 33 patients.

The majority of the involved nodes were submandibular lymph nodes, superior internal jugular nodes, and mid internal jugular nodes.

The five-year-survival rate was $84.1 \%$ in patients without metastasis and $46.4 \%$ with metastasis.

Prognosis was poorer as the number of metastatic nodes and sites increased. Prognosis was poorer as cervical nodes of lower level were involved.

Of the 33 cases with cervical lymph node metastasis, eleven cases died of local failure, but only one case died of failure in the neck. This indicates that the prognosis of cases with cervical lymph node metastasis depends upon whether the primary disease is controlled or not.
\end{abstract}

Key words: neck dissection (頙部郭消), cervical lymph node metastasis (頙部リン・節転移), local failure (原発果俳御)

\section{緒言 棓}

頸部りンバ節転移は、日腔癌の治療成綃を左石与る重

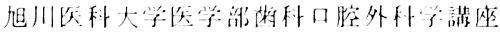

(主任：北進一教婹)

* 旭川赤十字拪院口腔外科

（主任：池烟正宕激垃）

Department of Oral and Maxillofacial Surgery, Asahikawa Medical College (Chief: Prof. Shinichi Kita)

* Department of Oral and Maxillofacial Surgery, Asahikawa Red ('ross Hospital (Chief: Dr. Masahiro Ikehata)

受付日：平成 3 年 7 月 $15 \mathrm{H}$
要な日子の1つである。頸部りンハ節転移の認められた 症例は転移のなかった症例之此較して子後不这である ふ，その原因は頸部転移巣それ日体のコントロールが難 しいためなのか、あるいは頸部りンパ節転移の諗められ た症例は腄場のひろがりが頸榊転移栄まで及んた進行例

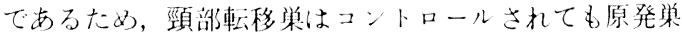
あるいは遠隔転移の制御がより困難なためなのか，い亦 だあきらかてはない当科では頸部リン・節転移に対し ては頸部剠清術を第一避択として治撩を行ってきた。今 㺫われわれは当科において頸部垶清術を施行した症例に ついて，頸部りン八節転移状況ならびにてれらと予後と の圆連を分析することにより，頸部リンパ節転移症例の

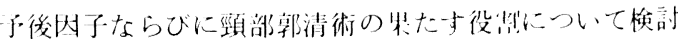
したので報售する。 


\section{対象と研究方法}

対象とした症例は1979年 1 月から1988年12月までの10 年間に旭川医科大学附属病院歯科口腔外科て治療した口 腔扁平上皮癌新鮮症例96例のうち, 上頚部郭清術を含吉 頸部郭清術を施行し治療後 2 年以上経過観察をし得た 53 例（71側）である.

原発部位および進展度を UICC の TNM 分類(1987 年）に従って分類すると, 舌21例，口底15例，下顎歯肉 9 例, 賽粘膜 7 例, 上顎歯肉 1 例で, T 15 例, T 2 24例，T 3 14例，T 4 10例であった（表 1 ）.

表 1 対象症例

\begin{tabular}{|c|c|c|c|c|c|c|}
\hline \multirow{2}{*}{ 原発部位 } & \multirow{2}{*}{$\begin{array}{l}\text { 一次 } \\
\text { 症例数 }\end{array}$} & \multicolumn{5}{|c|}{ 頸部郭消例数（例） } \\
\hline & & $\mathrm{T} 1$ & $\mathrm{~T} 2$ & T 3 & $\mathrm{~T} 4$ & 計 \\
\hline 舌 & 40 & 4 & 10 & 7 & & 21 \\
\hline 口底 & 18 & 1 & 5 & 3 & 6 & 15 \\
\hline 下顎迷肉 & 13 & & 2 & 3 & 4 & 9 \\
\hline 頓粘膜 & 15 & & 6 & 1 & & 7 \\
\hline 上顎幽肉 & 10 & & 1 & & & 1 \\
\hline 計 & 96 & 5 & 24 & 14 & 10 & 53 \\
\hline
\end{tabular}

表 2 頸部郭清の範囲と治療態度

\begin{tabular}{c|l|l|l}
\hline & 全頸部 & 上頸部 & 計 \\
\hline 子防的郭清沜 & 13 & 8 & $21(30 \%)$ \\
治療的郭清徒 & 44 & 6 & $50(70 \%)$ \\
\hline 計 & $57(80 \%)$ & $14(20 \%)$ & 71 \\
\hline
\end{tabular}

(㑡)
53名に対し71側に頸部郭清術を施行した。頸部郭清術 の内訳は治療的全頸部郭清術が $62 \%$ （44側）を占め，主 体をなしていた（表 2).

リンパ節の検索は術後ただちに摘出標本からリンパ節 を摘出し，所在部位，個数などを記録した後，10\%ホル マリン固定し, 病理学的に転移の有無を唡討した。

頸部リン八節は頭頸部癌取り扱い規約1 に彷って, オ トガイ下リンパ節，䪽下リンパ節，前頸部リンパ節，上 内深頸りンバ節, 中内深頸りンパ節, 下内深頸りンバ節, 外側内深顓リンハ節，鎖骨上窝りンバ節，副神経リンパ 節の 9 つの区域に分類した（図1）.

臨床的㛟討は頸部郭清の頻度, 頸部郭清術施行時期に ついて, 原発栄の進展度別および原発部位別に比軟娭討 した。次に病理組織学的検討を行い, 組織学的転移度, 正誤診率, 転移部位と転移りンパ節の個数, 転移状況之 予後之の関倸, 二次的郭清例之局所再発後郭清例の予後 について分析した，最後に頸部リンハ節転移症例の死因 について検討した。

\section{結果}

\section{1. 頸部郭清の頻度ならびに組織学的転移度}

原発巣の進展度と頸部郭清の頻度（頸部郭清術施行 率）との関倸をみる， T $127.7 \%$ ， T $251.1 \%$ ， T $373.7 \%$, T 4 83.3\%で, 原発巣の進展度が大きくな るにつれて頸部郭清の頻度も高かった。 また全経過を通 しての組織学的転移度（転移率）はT 1 , T 2 では約 25 \%，T 3，T 4 ではいずれも50\%以上であった（表了）.

原発部位と頸部郭清の頻度との関係をみると, 口底が 83. $3 \%$ で最も高く，次いで下䋶歯肉 $69.2 \%$ ，舌 $52.5 \%$ で，上顎歯肉が最も低くて10\%であった。また転移率を 原発部位別にみると, 口底が55.5\%で最も高く, 次いで 下䫇歯肉 $46.2 \%$, 舌 $32.5 \%$ で，上頸買蒾肉は $10 \%$ て最も 低かった（表 4).
$\mathrm{A} ：$ オガイ下リンパ節
$\mathrm{B} ：$ 顎下リンバ節
$\mathrm{C} ：$ 前頸部リンパ節
$\mathrm{D}$ ：上内深頸リンハ節
$\mathrm{E}$ ：中内深䁰リンパ節
$\mathrm{F}$ ：下内深頸リンパ節
$\mathrm{G}$ ：外側内深頸リンペ節
$\mathrm{H}$ : 鎖骨上窩リンパ節
I：副神経リンパ節

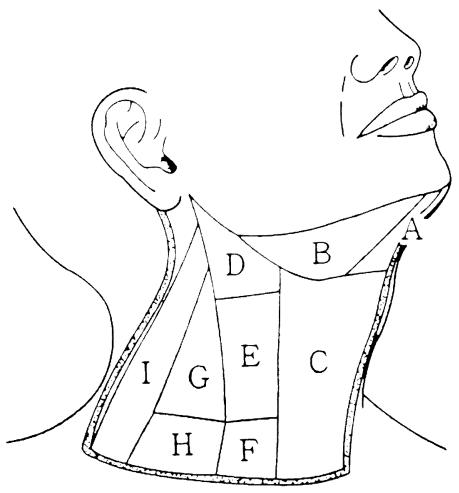

図 1 頸部リンパ節の分類 
表 3 原発栄進展度別頸部郭清の頻度ならびに組織学的転移度

\begin{tabular}{|c|c|c|c|}
\hline 進展度 & 一次症例数 & $\begin{array}{c}\text { 頸部郭清例数 } \\
\text { (雃部郭清施行率\%) }\end{array}$ & $\begin{array}{c}\mathrm{pN}(+) \text { 症例数 } \\
(\text { 転移率 } \%)\end{array}$ \\
\hline $\mathrm{T} 1$ & 18 & $5(27.7 \%)$ & $4(22.2 \%)$ \\
\hline T 2 & 47 & $24(51.1 \%)$ & $12(25.5 \%)$ \\
\hline T 3 & 19 & $14(73.7 \%)$ & $11(57.9 \%)$ \\
\hline T 4 & 12 & $10(83.3 \%)$ & $6(50.0 \%)$ \\
\hline 却 & 96 & $53(55.2 \%)$ & $33(34.4 \%)$ \\
\hline
\end{tabular}

表 4 原発部位別頙部郭消の頻度ならびに組織学的転移度

\begin{tabular}{|c|c|c|c|}
\hline 原発部位 & $\begin{array}{l}\text { 一次 } \\
\text { 症例数 }\end{array}$ & $\begin{array}{c}\text { 頸部郭清例数 } \\
\text { (頸部部清施行率\%) }\end{array}$ & $\begin{array}{c}\mathrm{pN}(+) \text { 症例数 } \\
(\text { 転移率 } \%)\end{array}$ \\
\hline 舌 & 40 & $21(52.5 \%)$ & $13(32.5 \%)$ \\
\hline 口底 & 18 & $15(83.3 \%)$ & $10(55.5 \%)$ \\
\hline 下顎楼肉 & 13 & $9(69.2 \%)$ & $6(46.2 \%)$ \\
\hline 頓粘膜 & 15 & $7(46.7 \%)$ & $3(20.0 \%)$ \\
\hline 上顎选肉 & 10 & $1(10.0 \%)$ & $1(10.0 \%)$ \\
\hline 尌 & 96 & $53(55.2 \%)$ & $33(34.4 \%)$ \\
\hline
\end{tabular}

転移率 $(\%)=\mathrm{pN}(+)$ 症例数 $/$ 一次症例数

表 5 原発栄進展度と頚部郭消術施行時期

\begin{tabular}{|c|c|c|c|c|c|c|c|}
\hline 原発单 & & & 施行 & 時 期 & & & \multirow{3}{*}{ 計 } \\
\hline \multirow[t]{2}{*}{ 進展度 } & \multicolumn{2}{|c|}{ 一次的部清 } & \multicolumn{2}{|c|}{ 二次的部清 } & \multicolumn{2}{|c|}{ 局所再発後郘清 } & \\
\hline & 治療的 & 予防的 & 治療的 & 予防的 & 治療的 & 予防的 & \\
\hline $\mathrm{T} 1$ & & 1 & 3 & & 1 & 1 & 6 \\
\hline $\mathrm{T} 2$ & 12 & 11 & 3 & & 2 & 1 & 29 \\
\hline T 3 & 11 & 4 & 1 & & 3 & 2 & 21 \\
\hline $\mathrm{T} 4$ & 14 & 1 & & & & & 15 \\
\hline 計 & 37 & 17 & 7 & & 6 & 4 & 71 \\
\hline
\end{tabular}

(側)

\section{2. 頸部郭清術施行時期}

原発栄の治療と同時かあるいは 2 か月以内に頻部郭清 術を行ったものを一次的垶清, 原発然治療後, 局所再発 なく経過中に転移を認め頻部郭清術を行ったものを二次 的郭清, 局所再発後に頸部郭清術を行ったものを局所再 発後郭清と寸ると，一次的郭清が42例54側，二次的郭清 が 7 例 7 側, 局所再発後郭清が 8 例10側で一次的郭清例 が圧倒的に多かった，二次的郭清例のらち 4 例は一次治 療後 2 年以内に施行されており, 原発巣江再発なく最も 遅く頼部リンパ節転移が出現したのは舌の症例で，一次
治療後 4 年 9 か月であった。

原発巣の進展度との関係をみると, T 1 症例で法半数 以上が二次的郭清で，一次的郭清はわずかに 1 例の及で 西ったが，T 2，T 3 症例では一次的郭清が70 80\%を 占め, T 4 症例では全例がー次的郭清であった。

治療態度との関保をみると, 一次的郭清の $30 \%$, 局所 再発後郭清の $40 \%$ が予防的就清であったのに対し, 二次 的郭清は全例治療的郭清であった（表 5).

原発部位との関係をみると, 上頡雬肉以外の部位に拈 いては一次的郭清が压倒的に多く, 二次的郭清は舌, 口 
表 6 原発部位と頸部勍消街施行時期

\begin{tabular}{|c|c|c|c|c|c|c|c|}
\hline \multirow[t]{2}{*}{ 原発部位 } & \multicolumn{2}{|c|}{ 一次的䀐清 } & \multicolumn{2}{|c|}{ 二次的郭清 } & \multicolumn{2}{|c|}{ 局所再発後郭消 } & \multirow{2}{*}{ 計 } \\
\hline & 治療的 & 予防的 & 治療的 & 予防的 & 治療的 & 予防的 & \\
\hline 舌 & 13 & 4 & 3 & & 3 & 4 & 27 \\
\hline 口底 & 16 & 6 & 3 & & & & 25 \\
\hline 下顎菌肉 & 5 & 4 & & & 2 & & 11 \\
\hline 頓粘膜 & 3 & 3 & & & & & 7 \\
\hline 上顎歯肉 & & & 1 & & 1 & & 1 \\
\hline 計 & 37 & 17 & 7 & & 6 & 4 & 71 \\
\hline
\end{tabular}

(㑡)

底に，局所再発後郭清は舌に多かった（表 6 ）。

\section{3. 正誤診率}

郭清の範囲別，ならびに治療態度別に組織学的転移陽 性の頻度をみると，予防的郭清 21 側中 5 側 (23.8\%)， 治療的郭清50側中 34 側 $(68 \%)$ が転移陽性であった。

臨床診断の正診率は70.4\%であった。䛊診率は $29.6 \%$ $て$ false positive ratio $222.5 \%$, false negative ratio は7.0\%であった（表 7).

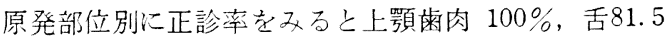
$\%$ ，口底，下顎歯肉が $60 \%$ 台，煩粘膜が $57.1 \%$ と最も低 かった (表 8).

\section{4. 転移部位と転移リンパ節の個数}

転移りンパ節は顎下リンパ節, 上内深頸リンパ節, 中 内深頸りン・節に多く,これら 3 部位で $75 \%$ 以上を占め ていた。

一次的郭清例では，組織学的に転移を認めた23例中転 移リンパ節が 1 個の症例は12例， 2 個症例 3 例， 3 個症 例 2 例， 4 個以上の症例 6 例であった。 4 個以上の 6 例 の5ち4 例は両側に転移が認められた。転移りンパ節が 1 個症例では12例中 7 例 $(58.3 \%)$ が顩下リンパ節, 3 例 $(25 \%)$ が上内深頸りンバ節への転移で、ほとんどの 症例がこの 2 部位に集中していた。また複数部位に転移 が認めら机たものはこの2 部位のいずれかに転移を認め た。二次的郭清例，局所再発後郭清例においても同様の 傾向が認められた（表 9 ).

原発巣と転移部位については舌では䫇下部，上下頸 部，さらに鎖骨上䈪，副神経に広く分布していたが，口 底てはオトガイ下リンパ節への転移が $12.5 \%$ 認められた 点が特徴的であった。また全例において前頸部りン・節 への転移は認められず，副神経リンパ節への転移は舌の 二次的郭清例において1個認められたたけであった。

\section{5. 転移状況と予後との関係}

一次的郭清例について累積生存率を Kaplan-Meier 法 により算出し, 雨群間の有意差検定をLogrank test と 一般化 Wilcoxon test を用いて行い, 以下の娭討を行
表 7 組織学的転移の有無

\begin{tabular}{c|c|c|c|c}
\hline & 側 & $(+)$ & $(-)$ \\
\hline $\begin{array}{c}\text { 予 } \\
\text { 防 } \\
\text { 的 }\end{array}$ & 全頸部 & 13 & 3 & 10 \\
\hline 上頸部 & 8 & 2 & 6 \\
\hline $\begin{array}{c}\text { 治 } \\
\text { 療 }\end{array}$ & 全頸部 & 44 & 31 & 13 \\
上頸部 & 6 & 3 & 3 \\
\hline & 計 & 71 & 39 & 32 \\
\hline
\end{tabular}

正診萧 : $50 / 71=70.4 \%$

䛊診率: $: 21 / 71=29.6 \%$

false positive ratio: $16 / 71=22.5 \%$

false negative ratio: $5 / 71=7.0 \%$

表 8 原発部位別正誤診率

\begin{tabular}{|c|c|c|c|}
\hline 原発部位 & 正診率 & $\begin{array}{l}\text { false } \\
\text { positive }\end{array}$ & $\begin{array}{l}\text { false } \\
\text { negative }\end{array}$ \\
\hline 舌 & $\begin{array}{l}81.5 \% \\
(22 / 27)\end{array}$ & $\begin{array}{l}18.5 \% \\
(5 / 27)\end{array}$ & \\
\hline 口底 & $\begin{array}{l}64.0 \% \\
(16 / 25)\end{array}$ & $\begin{array}{c}28.0 \% \\
(7 / 25)\end{array}$ & $\begin{array}{r}8.0 \% \\
(2 / 25)\end{array}$ \\
\hline 下靧蒱肉 & $\begin{array}{c}63.6 \% \\
(7 / 11)\end{array}$ & $\begin{array}{c}18.2 \% \\
(2 / 11)\end{array}$ & $\begin{array}{r}18.2 \% \\
(2 / 11)\end{array}$ \\
\hline 頓粘膜 & $\begin{array}{l}57.1 \% \\
(4 / 7)\end{array}$ & $\begin{array}{l}28.6 \% \\
(2 / 7)\end{array}$ & $\begin{array}{c}14.3 \% \\
\left(\begin{array}{c}1 / 7\end{array}\right)\end{array}$ \\
\hline 上顎紫肉 & $\left.\begin{array}{c}100 \% \\
1 / 1\end{array}\right)$ & & \\
\hline 計 & $\begin{array}{c}70.4 \% \\
(39 / 71)\end{array}$ & $\begin{array}{l}22.5 \% \\
(16 / 71)\end{array}$ & $\begin{array}{r}7.0 \% \\
(5 / 71)\end{array}$ \\
\hline
\end{tabular}

った。

1) 頸部リンパ節転移の有無とその子後

組織学的に転移を認めた症例と認めなかった症例の予 後を比較すると, 転移を認めた症例では 5 年, 10年累積 
表 9 転移リンパ節の個数と転移部位

\begin{tabular}{|c|c|c|c|c|c|c|c|c|c|c|c|c|}
\hline \multirow[b]{2}{*}{ 転移部位／転移リンパ節数 } & \multicolumn{4}{|c|}{ 一次的郭清 } & \multicolumn{4}{|c|}{ 二次的郭清 } & \multicolumn{4}{|c|}{ 局所再発後郭清 } \\
\hline & 1 & 2 & 3 & $4 \leqq$ & 1 & 2 & 3 & $4 \leqq$ & 1 & 2 & 3 & $4 \leqq$ \\
\hline A & & 1 & & & & & & & & & & \\
\hline B & 7 & & & & 1 & & & & 2 & & & \\
\hline $\mathrm{D}$ & 3 & & & & 2 & & & & 1 & & & \\
\hline E & 1 & 1 & & & & & & & & 2 & & \\
\hline $\mathrm{F}$ & 1 & & & & 1 & & & & & & & \\
\hline$B+E$ & & 1 & & 1 & & & & & & & & \\
\hline$B+D+E$ & & & 2 & 1 & & & & 1 & & & & \\
\hline$B+E+F$ & & & & 1 & & & & & & & & \\
\hline $\mathrm{D}+\mathrm{E}+\mathrm{H}$ & & & & & & & & & & & & 1 \\
\hline 4 部位以上 & & & & 3 & & & & 1 & & & & \\
\hline 計 & 12 & 3 & 2 & 6 & 4 & & & 2 & 3 & 2 & & 1 \\
\hline
\end{tabular}

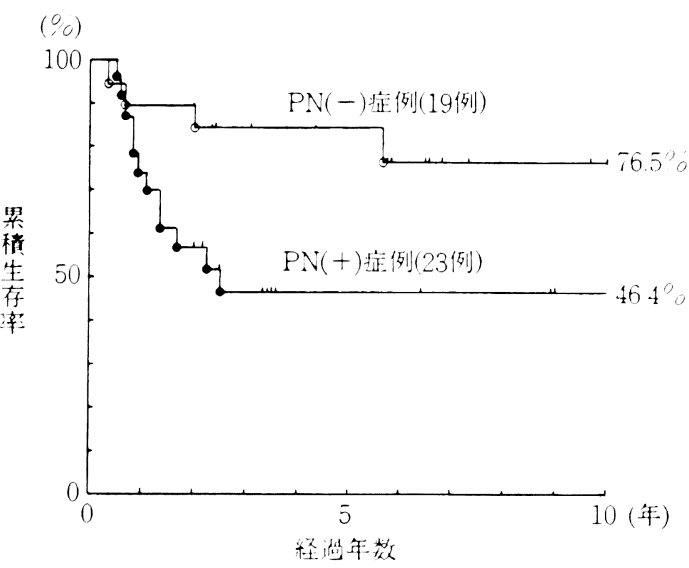

図 2 頸部リン・節転移の有無別生存率

生存率とも $46.4 \%$, 転移落認めなった症例では 5 年 $84.1 \% ， 10$ 年 $76.5 \%$ で，両群間の有意差検定を行うと一 般化 Wilcoxon testによる蚞定では有意差を認めなかっ たが，Logrank testによる検定では有意差（ $\mathrm{p}<0.05 ）$ を認めた（图 2)。

2) 転移リンパ節の個数, 転移部位の数ならびに転移 部位とその子㷋

転移りンパ節が 1 個のみの症例（12例）と複数個の症 例（11例）の予後を比較すると，5年，10年累積生存率 とも1個のみの症例では75\%であったのに対し, 複数個 の症例では0\%で，Logrank test $(\mathrm{p}<0.01)$ でも一般 化 Wilcoxon test $(\mathrm{p}<0.05)$ でも両群間に有意差を認 めた（図了）。

転移リンパ節が1部位にのみ認められた症例（14例）

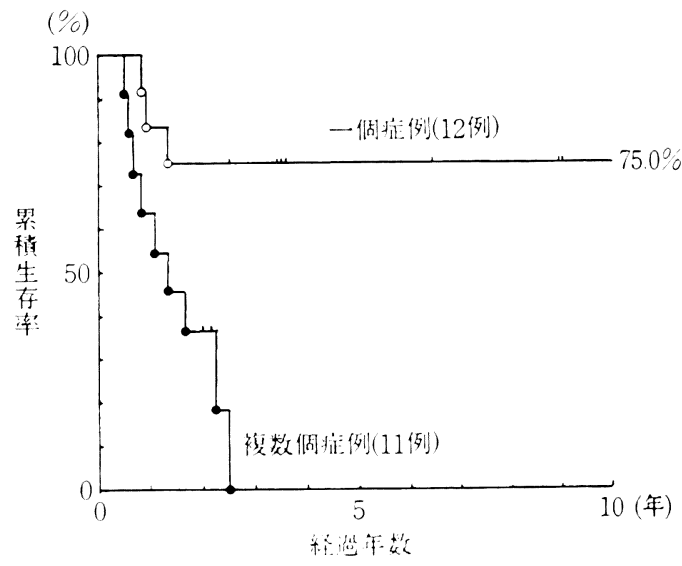

図 3 転移リン・節個数別生存率

と複数部位に転移が認められた症例（9 例）の予後を比 較すると，5年，10年累䅡生存率々も1部位症例では $71.5 \%$ ，複数部位症例では $0 \%$ で，Logrank test（p< 0.01）でも一般化 Wilcoxon test $(\mathrm{p}<0.05)$ でも両群 間に有意差を認めた（図4）。

オトガイ下リンス節，龥下リンハ節，上内深頸りンハ 節を一次りンバ節（図1 $\mathbf{A}, \mathbf{B}, \mathbf{D}$ ) とし, これら以外 のリンパ節を二次りンパ節（図1 $\mathbf{C}, \mathbf{E} \sim \mathbf{I}$ ）とする と, 一次リンパ節のみに転移が認められた症例は11例 で，その 5 年, 10年累積生存率はともに $72.7 \%$ であっ た。これに対し二次りンパ節に転移が認められた症冽は 12例で，その 5 年, 10年累積生存率はともに $20.9 \%$ て, Logrank test でも一般化 Wilcoxon test でも両群間に 有意差（p<0.05）を認めた（図 5 ）. 


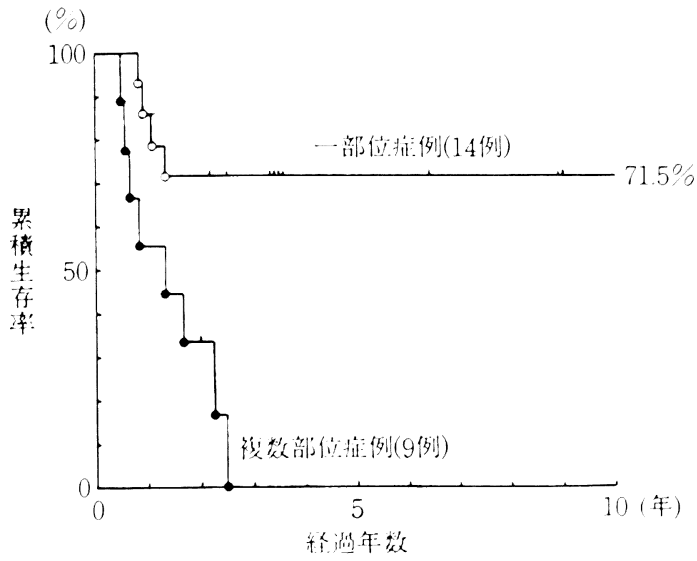

図 4 転移部位数別生存率

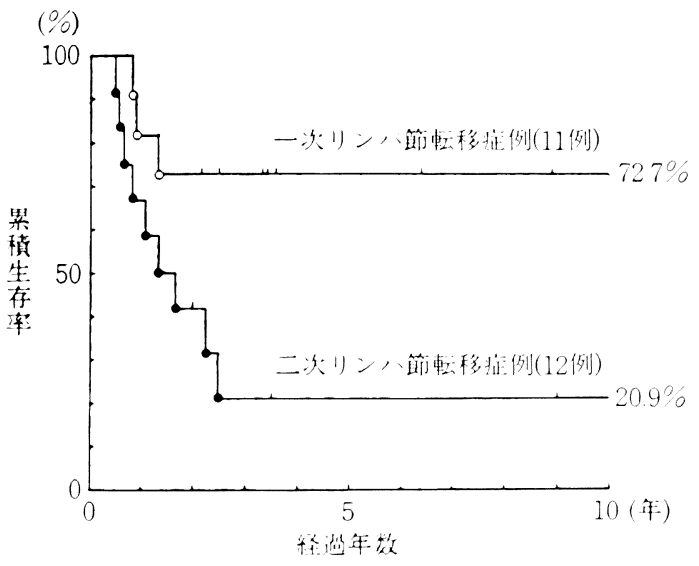

図 5 転移部位別生存㴭

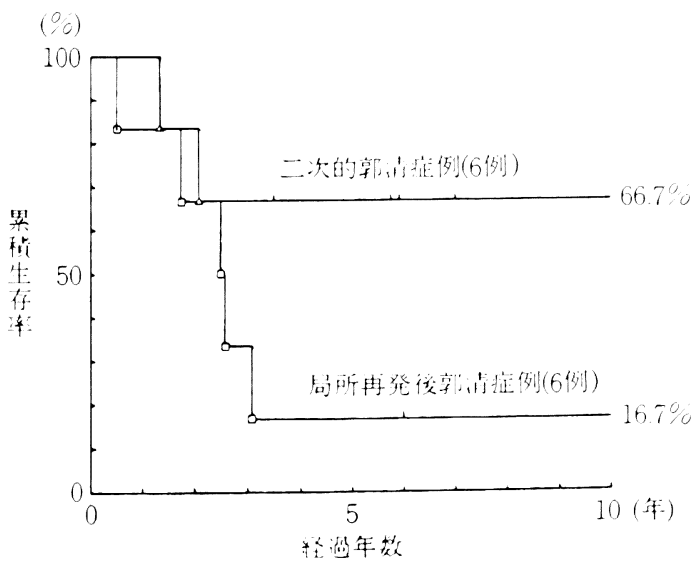

図 6 新溃栚式別生存率
表 10 頙部りン、節転移症例の死亡原因

\begin{tabular}{c|c}
\hline 死亡原因 & 症例数 \\
\hline 原発果死 & 11 \\
预部転移柴死 & 1 \\
㬊隔転移死 & 3 \\
他病死 & 3 \\
\hline 計 & 18 \\
\hline
\end{tabular}

\section{6. 二次的郭清例と局所再発後郭清例の予後}

二次的郭清例 7 例の5ち組䢂学的法転移認的た症例 は6 例であった。一方, 局所再発後郭清例では治療的郭 清を行った 6 例全例に組織学的汇転移を認めた。これら 組織学的に転移老認心た二次的郭清例 (6 例) と局所再 発後郭清例（6 例）について，累程生存率を KaplanMeier 法により求め, 両群間の有意差椧定を Logrank test と一般化Wilcoxon test を用いて行い予後を比較 すると, 5 年，10年累諎生存率とも二次的郭清例ては， $66.7 \%$ ，局所再発後朝清例ては $16.7 \%$ て，原発坚の制御 されている二次的郭清例の方が予後良好で，明確な有意 差は認的なかったが有意傾向学認めた（図6）。

\section{7. 頸部リンパ節転移症例の死因}

組穖学的に頸部りンハ節転移を認めた33例中18例が死 亡し, その死亡原因は原発栄死11例，遠隔転移死 3 例， 他病死 3 例で, 頸部転移巣死は 1 例のみであった(表10)。 またこの頸部転移栄死死例は高度の節外浸潤型のリンハ 節転移であった。

考

察

\section{1. 転移頻度}

口腔癌の頸部りン人節転移頻度は報告者により差があ るが，注注30〜 50\%で，転移頻度の高い原発部位として 舌をあ!゙る報告が多い2 、出 今回のわれわれの梌索ては， 口腔扁平上皮癌一次症例96例中, 頸部敦清術走行い, 組 織学的に転移を確認し地症例は 33 例 $(34.4 \%)$ で市っ た。原発部位ては口底が55.5\% と最も高く，上頻幽肉が

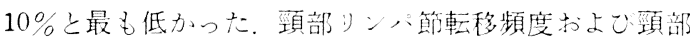
郭清頻度は原発染の進殿度に比例して高くなるといわれ

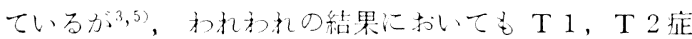
例では約 $25 \%$ に T 3 , T 4 症例では $50 \%$ 以上に組織学 的に転移が認められ，頸部新清の频度も原発栄の進展度 に比例して高くなった。

\section{2. 頸部郭清術施行時期}

原発栄の進展度に比例して初診時化頸部りン八節転移 索認める症例が多くなるため，原発巣が進展するにつれ

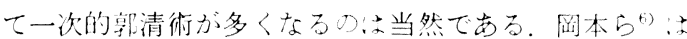
T 2, T 3 症例ては70\%, T 4 症例ては全例が一次的就 
清症例であったと述べているが，われわれも同じ結果で あった， T 4 症例に二次的郭清症例, 局所再発後郭清症 例が 1 例もなかったが, その理由として, 原発巣がT 4 程度の大きさになると頸部りンハ節転移が出現するもの は初診時の段階で認められることが多いこと， T $4 \mathrm{~N} 0$ 症例でよ一次治療時に予防的朝清を行っていることが多 いこと, 再建術の進歩に伴い, 最近は T 4 症例に対して 一次治療時に積極的に広範囲切除術を行っているため再 発時には手術不可能な状態になっていること, すなわち 初回手術が最終手術になっていることが多いことなどが 考元られる。

後発钼部リンパ節転移は一次治療後 1 年以内に出現す ることが多い、6)といわれている. 今回われわれは一次治 療終了 2 か月以後に局所再発なく䫓部リンパ節転移した ものを後発頸部りン・節転移としたが，6例中 4 例が 1 年以徯に出現し, 最も遅く出現したのは 4 年 9 か月後て あった。これは徉来の報告 $3,6,7)$ とは異なっていたが，今 回の結果から一次治療後, 1 年以内の政重な経過観察は もち万んのこと, 長期にわたる释過観察が必要と思われ た。また後発頸部りン八節転移は舌癌に多いといわれて いるマ 9)，が自娩例でも6例中 3 例が舌癌であった。

\section{3. 正誤診率}

診断能力の目安となる正診率は, 諸家の報告 ${ }^{2,9 \sim 12)}$ は35\%から81\%でわれわれの正診率は70.4\%であっ た。野谷ら は原発部位別の正骖率について娭索し， 舌, 口底の正診率は高く, 下靧は低かったと述べている が，われわれの場合は，舌の正診率は高かったが，口底， 下顎柬肉は低かった。特に下顎柬肉では false negative か.18.2\%と高く、診断の難しさが示された。䛊診の原因 としては炎症による反応性のリンパ節腫脹と転移性りン ，節腫脹との鑑別が難しいこと，上内深澒りンバ節は解 剖学的に胸鎖乳突筋の下層にあるたか触知しにくいこと などが考えられる。このよ5に触䛦による診断には限界 があるため, 最近はCT, MRI, 超音波骖断などの画像 䛦断を併用しているところが多( 2,13 17) Baatenburg ら ${ }^{13}$ ( は頸部りンハ節転移に対与る触診, 超音波骖断, 超 音波骖断之穿刺吸引紐胞䛦との組又合わせの3 種類の䛦 断方法による正骖率を比較し，触䛦では70.8\%，超音波 䛦断で $83.3 \%$ であったが，超音波骖断之穿刺吸引紏胞 骖を組又合わせると95.2\%にまで向上したと報告してい る。一方, Feinmesser $5^{14}$ 法触骖とCT とては診断能 力に差はなかったといい，画像䛦断はあくまでも補助骖 断に過きないと强調している。われわれも画像診断を併 用し船合的二骖断しているが, 画像骖断の場合, 䛦断基 隼の設定が難しく, 今徭より信頼性の高い診断基準の確 立が望まれる。

\section{4. 転移リンパ節の個数と転移部位}

転移部位としては敫下りンバ節が最も多く，次いで 上, 中深湏リンハ節で,これら 3 部位て $75 \%$ 以上を占め
ていた，特に一次的郭清例ては転移りンパ節 1 個症例12 例中10例が顎下リンパ節，上内深頸リンパ節への転移 で，複数部位転移例てはこの 2 部位のいずれかに転移を 認めた。諸家の報告 $2,4,6)$ も同様で, これら2 部位は口膑 扁平上皮癌の転移好発部位と考えられた。

オトガイ下リンハ節には転移が少ないといわれてい る ${ }^{4,5)}$ が、本間 ${ }^{4)}$ は、オトガイ下リンバ節へ転移が認めら れた症例はすへて他の部位にも転移が認められたことか ら，逆行性転移の可能性が考えられるといい，小野ら はこの部位に転移したものは，予後不良であると述べて いる．自験例ではこの部位へ転移したものは口底癌の 2 例のみで，5ち1例はオトガイ下リンパ節のみに転移を 認め, 阔本ら ${ }^{6)}$ の指摘した直接流れ込むりンハ流の存在 を支持する結果であった。

副神経リンパ節への転移は非常に少ないとい5報告2 7)が多いが, 自験例でも舌癌の後発頸部リンパ節転移例 の1例のみであった。ただし，この症例は頸部多発リン パ節転移例て， Schuller ら ${ }^{18)}$ の述べているよらにこの 部位に転移したものは予後不良であることが示唆され た。

\section{5. 転移状況と予後の関俰}

組䅧学的転移陽性例の予後は不良であるといわれてい $ろ^{2,3,6 \sim 9)}$ が, 自駼例でも一次的郭清例では pN (+) 群 の 5 年累積生存率は $46.4 \%$ で, pN (一) 群の 5 年累積 生存率 $84.1 \%$ ら悪かった。 $\mathrm{pN}(+)$ 症例の予後に影 辢を及注寸因子については多方面から検討されている が，その1つに転移状況の違いがあり，転移リンハ節の 数, 転移部位, 転移部位の数, 大きさ, 固定の有無など が子徭に関係していると考えられる。

転移リンパ節の数と子後の関係については, 個数が多

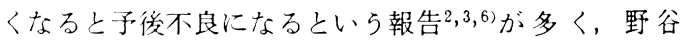
ら 2)は3 個以上になると生存率が極端に低下寸るため,

3 個以上は子後因子になりらると述べている。われわれ の症例でも, 複数個症例の子後は 1 個症例に比べ不良 で, 特に 3 個以上の症例は全例 3 年以内に死亡してい て，野谷ら 2)の見解を支持する結果であった。

転移部位と予後との関係ては, 一次リンパ節に転移を 梁めた症例の活5が後良好であった。野ら゙は子後 に影劉を与える因子として転移りン八節の数と部位を比 較した場合，部位の方が重要であると述べているが，わ れわれの娭討ではあきらかな傾向は認められなかった。

転移部位の数上子後の関係について，風本ら ${ }^{6)}$ は転移 部位が複数になると子後は悪く，転移リンバ節の個数や 転移部位よりも転移部位の数が最も子後に影㸷を及ほすす 因子であると述べている。自験例では複数部位に転移を 楒めた症例は 1 部位症例より予後不良であったが, 複数 部位に転移した症例は当然のことながら複数個症例であ り，しかも必ず二次リンパ節にも転移を伴っていたた め, 個数、転移部位, 転移部位の数のらちどれが最も子 
表 11 転移リン，節の個数ならびに転移部位の数と子後

\begin{tabular}{|c|c|c|c|c|c|c|c|c|c|c|c|c|}
\hline \multirow[b]{2}{*}{ 転移部位／転移リンハ節数 } & \multicolumn{4}{|c|}{ 一次的勃消 } & \multicolumn{4}{|c|}{ 二次的䣎消 } & \multicolumn{4}{|c|}{ 局所再発後勃溥 } \\
\hline & 1 & 2 & 3 & $4 \leqq$ & 1 & 2 & 3 & $4 \leqq$ & 1 & 2 & 3 & $4 \leqq$ \\
\hline A & & 0 & & & & & & & & & & \\
\hline B & $\begin{array}{l}000 \\
000 \\
0\end{array}$ & & & & $\Delta$ & & & & $\mathbf{a} \times$ & & & \\
\hline $\mathrm{D}$ & $\bullet \bullet \bullet$ & & & & $\circ \Delta$ & & & & $\bullet$ & & & \\
\hline E & $\bigcirc^{*}$ & $\bullet$ & & & & & & & & - & & \\
\hline F & 0 & & & & $0^{*}$ & & & & & & & \\
\hline$B+E$ & & 0 & & $\bullet$ & & & & & & & & \\
\hline $\mathrm{B}+\mathrm{D}+\mathrm{E}$ & & & $\bullet$ & $\bullet$ & & & & 0 & & & & \\
\hline$B+E+F$ & & & & $\bullet * *$ & & & & & & & & \\
\hline $\mathrm{D}+\mathrm{E}+\mathrm{H}$ & & & & & & & & & & & & -* \\
\hline 4 部位以上 & & & & $\bullet \boldsymbol{\Delta} \mathbf{\Delta}$ & & & & 0 & & & & \\
\hline 計 & 12 & 3 & 2 & 6 & 4 & & & 2 & 3 & 2 & & 1 \\
\hline
\end{tabular}

传に対して影暗しているか判断てきなかった。

\section{6. 二次的郭清例と局所再発後郭清例の予後}

二次的部清例の 5 年累皘生存罍: $66.7 \%$ で, 局所再発 後垶清例の 5 年累磧生存率 $16.7 \%$ と大きな差があった。 しかも二次的郭清例ては，他病死した 2 例支除くと，転 移りン，節の個数，転移部位，転移部位の数に関倸なく， 全例生存していたか，局所再発後影清例ては転移りンハ 節の個数，転移部位，転移部位の数に関係なく子传不良 であった（表11）。これは原発祭の制御が予後により大 きな影梨を及ぼしているとを示唆している。

\section{7. 頸部リンパ節転移症例の死因}

頸部りン・節転移症例が転移のない症例と比較して子 後不良なのは，頸部転移栄それ自体の御制が難しいため なのか，それとも頸部転移巣は制御されても原発栄ある い:遠隔転移の制御がより困難なためなのか、いまだあ きらかではない，自駼例では頸部りン八節転移症例33例 中18例が死亡しているが, 死亡原因の大部分涼発柴死 で，頸部転移宩死さ1例のみであった。なお原発单不制 御によるものか, 項湖転移单の不制御によるものか鑑別 が難しかった頸部皮底再発症例か３例方り，こ机らは原 発单死に含めたか，仮にこれら 3 例莸頸部転移果死に含 めたとしても頸部郭清術て頸部転移果の制御に失敗した

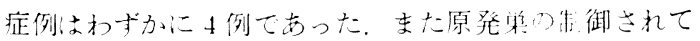
いる二次的郭清例之制御されていない局所再発後郭清例 の 5 年累積生存率はそれぞれ $66.7 \% ， 16.7 \%$ で大きな差 があった。このことから頸部リン八幯転移症例の予後が 不良なのは，頸部転移巣乙れ自体の制御失敗によるので は衣く，大部分が原発巣の不制御によることが示唆され

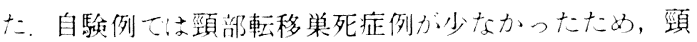

部転移栄乙九自体の制御に関与寸る因子については㛟討 できかった。しかし自駼例の頸部転移果死症例 1 例求 よび頚部皮咸再発症例 3 例がい寸゙れも高度の節外浸潤り ンハ節であったこと,ならびに网本ら ${ }^{6)}$ の磒部転移栄死 の78.6\%が節外浸潤であったといら報告, 野公ら ${ }^{197}$ の同 側頸部再発率と病理学的浸潤度とは閔璉があるといら報 告から，頸部転移采乙机自体は高度の節外浸潤りン八節 以外のものであれは頸部晫清術によって制御可能である こと，すなわち頸部転移栄それ自体の制御に最も影響を 及注している内子は節外浸澗の程度である可能性が大き い今後、この点に関する詳綝な检討が必要と思示れ 万.

\section{8. 予防的郭清術}

予防的朝清術を行らべきかとらかに関しては議論か多 (2,3,6,7) 予防的款清を支持する根执としては，1）潜 在性りン八節転移が少なからお゙存在する，2）頙部郭清 術に上る死亡率はき扐めて低い，3）政重な経過観察を 行っていてもリン・節転移発見の時期が幄れることがあ る，4）頸部りン八節転移があると，遠隔転移の頻度も

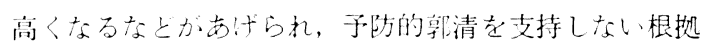
としては，1）啟重な経過観察によって頸部りン八節転 移は小さいらちに発見できる，2）潜在性りンハ節転移 には放射線治療が有効，3）不必要な例に乎手術老子る ことになり, 頸部朝清術の死亡率も低いとはいえない,

4) 予防的晫清によって, 免疫学的な転移の防御相が除 去される可能性があるなどがあげられる。

当科では上記理由に加公て子防的敦清の是非圭誨なる 5 えで重要な false negative ratio も低いため原則的に は予防的郭清は行っていない。しかし原発部孝手術する 
際，靧下三角部が手術野に含まれる場合には，原発巣の 大きさ，浸潤様式などを考虑して症例ごとに決めている のが現状である

\section{結語}

1979年 1 月から1988年12月までの10年間に当科で治療 した口腔扁平上皮癌新鮮症例96例の5ち, 上頸部郭清術 を含む頸部郭清術を施行した53例（71側）について頸部 リンバ節転移状況ならびにそれらと予後との関連につい て分析し，以下の結論を得た。

1. 頸部郭清術施行例53例中 33 例に組織学的転移を認 めた，全経過を通しての組織学的転移度はＴ１ $22.2 \%$, T $225.5 \%$, T $357.9 \%$, T $450.0 \%$ であった。 原 発部位では口底か $55.5 \%$ ，で最も高く，上買歯肉が $10 \%$ で最も低かった。

2. 頸部郭清術の内訳は, 治療的頸部郭清術が 50 例, 予防的頸部郭清術か2 21 例, 全頸部郭清術か57例, 上頸部 郭清術が14例であった。

3. 全例の正䛦率は $70.4 \%$, false positive ratio 22.5 \%, false negative ratio $7.0 \%$ であった。

4. 転移リンハ節分布では，買下りンパ節，上内深頸 リンハ節, 中内深頸リンパ節の 3 部位に集中し, この 3 部位で $75 \%$ 以上を占めた。また複数部位に転移が羿めら れたものは顎下リン・節と上内深頸リンハ節のいずれか 汇転移を認めた。副神経リンバ節に転移を認めたものは 1 例の久であった。

5. 組織学的江転移を認的た症例の 5 年累段生存率は 46.4\%であったのに対し，転移を認めなかった症例では 84. 1\%であった。

6. 転移リンハ節の個数，転移部位の数が複数になる と、また転移りンハ節の部位が下方になる汪ど予後が不 良であった。

7. 二次的部清例の 5 年累積生存率は $66.7 \%$ であった か，他病死を除くと全例生存していた。

8. 頸部りン八節転移症例の死因の大部分は原発栄死 で，頸部転移然死は1例のみであった。このことから頸 部りンン゙節転移症例の予後が不良なのは頸部転移单それ 自体の制御失敗によるのではなく，大部分が原発巣の不 制御によることが示嘫された。

\section{引用 文 献}

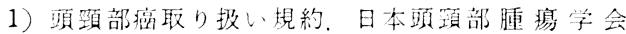
編，第 1 版，金原出版，東京，1982，2-4 頁。

2) 野谷揵一, 井上晨夫男, 他: 当科の频部就消例
の検討。 日只外誌 32：602-613 1986 .

3）小野勇, 暨津邦雄, 他：舌癌治瘵に打ける钼 部郭消術の評価。癌の臨床 26: 123-1301980.

4）本間義郎：口膑癌の頸部リンパ節転移に関刍る 研究。日口外誌 28：1667-1684 1982.

5) Lindberg, R.. Distribution of cervical lymph node metastases from squamous cell carcinoma of the upper respiratory and digestive tracts. Cancer 29: 1446-1449 1972.

6) 岡本学, 大関 悟, 他: 口腔癌に打ける颛部 郭清術施行例の検討。一頸部 リンバ節転移様相 と予後一 日口外誌 31：554-562 1985 .

7) 高田和彰, 遠藤邦彦, 他 : 口腔領域恶性腫湟の 頙部りンパ節転移に関する臨束統計的検討。日 口外誌 34: 872-878 1988.

8）小野勇：舌がんの予後に影響を及ばす因子の 研究. 一舌可動部がん221例の分析より一日 耳鼻 80：146-154 1977.

9）宮川明, 小浜源郁, 他：口腔癌の頸部リンハ 節転移に関与る臨床病理学的検討。一特に腫場 の浸潤様式との関速について一，日口外誌 29: 1555-1561 1983.

10）斎藤利夫, 手島貞一, 他：口腔領域扁平上皮癌 の領域りン・節転移に関する臨床統計的考察。 日口外誌 25: 778-783 1979.

11）作田正義，菅原利夫，他：頭频部扁平上皮癌の 転移形成汇関可臨床的研究。口科誌 30：1131981.

12）断垣 晋：口腔领域悪性腫演の頚部りンバ節転 移に関与る臨床病理学的研究。日口外誌 25 : 784-797 1979.

13) Baatenburg, R.J., Rongen, R.J., et al.: Metastatic neck disease. - Palpation ws ultrasound examination. Arch Otolaryngol Head Neck Surg 115: 689-690 1989.

14) Feinmesser, R., Freeman, J.L., et al.: Metastatic neck disease. - A clinical/Radiographic/ Pathologic corrective study-. Arch Otolaryngol Head Neck Surg 113: 1307-1310 1987.

15）石井純一, 天签光雄, 他: 口腔癌頙部転移りン “節の超音波扰上び CT による診断。 J Jpn Soc Cancer Ther 25: 2526-2532 1990.

16）内藤久美子：超音波䛦断に上る頙部りンパ節転 移の検討。日本医放会誌 50：918-927 1990 .

17）占川政樹：超音波断層法汇上る顕預部癌の頙部 リンハ笷転移の检討。耳鼻 35：876-888 1989.

18) Schuller, D.E., McGuirt, W.F., et al.: The prognostic significance of metastatic cervical lymph nodes. Laryngoscope XC': 557-570 1980.

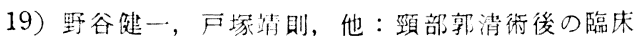
経過につい下。旺外誌 32：1641-1647 1986. 